File:Sautcomm.lwp

16-Feb-99

\title{
Effect of Growth Rate on Elevated Temperature Plastic Flow and Room Temperature Fracture Toughness of Directionally Solidified NiAl-31Cr-3Mo
}

\author{
J.Daniel Whittenberger ${ }^{1}$, S.V. Raj', I.E. Locci², and J.A. Salem ${ }^{1}$ \\ ${ }^{1}$ NASA-Lewis Research Center, Cleveland, OH, USA 44135 \\ ${ }^{2}$ Case Western Reserve University at LeRC, Cleveland, OH, USA 44135
}

\begin{abstract}
The eutectic system $\mathrm{Ni}-33 \mathrm{Al}-31 \mathrm{Cr}-3 \mathrm{Mo}$ was directionally solidified at rates ranging from 7.6 to $508 \mathrm{~mm} / \mathrm{h}$. Samples were examined for microstructure and alloy chemistry, compression tested at 1200 and $1300 \mathrm{~K}$, and subjected to room temperature fracture toughness measurements. Lamellar eutectic grains were formed at $12.7 \mathrm{~mm} / \mathrm{h}$; however cellular structures with a radial eutectic pattern developed at faster growth rates. Elevated temperature compression testing between $10^{-4}$ to $10^{-7} \mathrm{~s}^{-1}$ did not reveal an optimum growth condition, nor did any single growth condition result in a significant fracture toughness advantage. The mechanical behavior, taken together, suggests that Ni-33 Al-3 1Cr-3Mo grown at rates from 25.4 to $254 \mathrm{~mm} / \mathrm{h}$ will have nominally equivalent properties
\end{abstract}

\section{Keywords}
A. Nickel aluminides, based on $\mathrm{NiAl}$
B. Fracture Toughness
B. Mechanical Properties at elevated temperature
C. Directional solidification ${ }^{1}$

${ }^{1}$ Please note that I added this term since it does not exist in the current listing for section C (Processing). 


\section{Effect of Growth Rate on Elevated Temperature Plastic Flow and Room Temperature Fracture Toughness of Directionally Solidified NiAl-31Cr-3Mo \\ J.Daniel Whittenberger, S.V. Raj, I.E. Locci, and J.A. Salem}

\section{Introduction}

In comparison to commercial Ni-based superalloys, the B2 crystal structure intermetallic NiAl has higher thermal conductivity and melting point in combination with a lower density and superior oxidation resistance. This attractive combination of properties makes $\mathrm{NiAl}$ an ideal candidate material for replacement of superalloys in aircraft gas turbine engines. However, binary NiAl possesses poor elevated temperature creep properties and low room temperature fracture toughness which have limited its potential for use as a structural material.

Over the past decade, there has been a systematic effort to improve the high temperature creep properties of NiAl using solid solution alloying, precipitation hardening, dispersion strengthening, directional solidification and in/ex-situ composite processing techniques $[1,2]$. In particular, Dr. Sauthoff and his group at the Max-Planck Institute, Düsseldorf, Germany, have been actively engaged in the research and development of new NiAl-based alloys over the past decade and have advanced our understanding of the elevated temperature strengthening mechanisms in these materials [3-5]. Other studies [6] have demonstrated that NiAl single crystals containing $\mathrm{Ga}$, $\mathrm{Hf}$ and $\mathrm{Ti}$ result in precipitate/solid solution-strengthened alloys which possess high temperature tensile creep strengths comparable to the commerical single crystal alloy Rene'N4. Significantly, high pressure turbine vanes have been manufactured from these 
$\mathrm{NiAl}$ single crystal alloys and tested in a gas turbine engine $[7,8]$. Despite this remarkable success, the advanced NiAl single crystal alloys are known to be quite fragile with brittle-to-ductile transition temperatures (BDTT) varying between 1000 and $1425 \mathrm{~K}$ coupled with room temperature fracture toughness values on the order of $3-5 \mathrm{MPa} \cdot \mathrm{V}_{\mathrm{m}}$ which is believed to makes them unsuitable for critical turbine blade applications [9].

Incorporation of a ductile phase within the brittle matrix is one technique which has been investigated as a means to improve toughness. In particular, this methodology has been applied to NiAl-based systems through directional solidification (DS) of eutectic compositions, where the longitudinal axes of the eutectic phases align themselves parallel to the growth direction [9-18]. The quaternary 33Ni-33Al-(34-x)Cr-xMo $\{0 \leq x \leq 6\}$ system has drawn much interest since the

${ }^{1}$ All compositions are reported in at.\% unless otherwise reported.

early studies by Walter and Cline [19-21] demonstrated that substitution of Mo for $\mathrm{Cr}_{\mathrm{r}}$ leads to a change in the phase morphology from $\alpha-\mathrm{Cr}$ fibers in a NiAl matrix to alternating $\alpha-(\mathrm{Cr}, \mathrm{Mo})+$ NiAl lamellar plates when the Mo level exceeded $0.7 \%$. This latter phase arrangement offers the possibility of both increased fracture toughness and elevated temperature creep strength $[13,15]$.

In their investigations on NiAl-Cr(Mo) eutectic alloys, Cline and Walter [20] observed that well-aligned microstructures could be grown from the melt when the ds processing rates were less than $19 \mathrm{~mm} / \mathrm{h}$; however no clear dependency between the "goodness" of alignment and 
mechanical properties was reported. Since the economic viability of producing turbine engine parts at growth rates $\leq 19 \mathrm{~mm} / \mathrm{h}$ would be questionable, the behavior of this alloy after being grown at faster rates is desirable. Previous work has shown that the interlamellar spacing of many eutectic alloys decreases with increasing growth rate $[19,22]$ and that the mechanical properties tend to improve as the spacing decreases [22], faster growth rates should strengthen 33 Ni-33Al-31 Cr-3Mo through refinement of the lamellae. However, other microstructural features, such as cells, are also likely to become more prominent and would also decrease in size with an increasing processing speed which could lead to lower elevated temperature strength. As a result, it is expected that the strength of the $(\mathrm{Cr}, \mathrm{Mo})$-modified NiAl would exhibit a maximum as a function of ds growth rate. Indeed, this behavior was observed by Walter and Cline [19] in NiAl-34Cr.

The present investigation was undertaken to study the effect of growth rate on the microstructure and mechanical properties of DS 33Ni-33Al-31Cr-3Mo in order to answer several questions: 1) Does the microstructure vary with growth rate; 2) Does the elevated temperature strength show maxima as a function of growth rate; and 3) Is the fracture toughness affected by the growth rate? While tensile testing is generally considered to give the most relevant measure of useful mechanical strength of directionally solidified alloys, elevated temperature compressive tests were undertaken in this work for simplicity and the ability to obtain a reasonable number of specimens for testing from each DS bar. We felt that use of compression data was justified as previous testing [23] of several 33Ni-33 Al-31Cr-3Mo rods ds at $12.7 \mathrm{~mm} / \mathrm{h}$ demonstrated that the compression and the tensile results are comparable at $1300 \mathrm{~K}$ within the limits of 
experimental scatter (Fig.1). Similar behavior has also been observed in DS NiAl-14.5Ta [24] at both 1200 and $1300 \mathrm{~K}$.

\section{Experimental Procedures}

As-cast bars of $33 \mathrm{Ni}-33 \mathrm{Al}-31 \mathrm{Cr}-3 \mathrm{Mo}$, suitable for directional solidification, were prepared by initially induction melting a charge of $\mathrm{Al}, \mathrm{Cr}, \mathrm{Ni}$ and $\mathrm{Ni}-50 \mathrm{Mo}(\mathrm{wt} \%)$ in high purity alumina crucibles under argon. The liquid metal was cast into a copper chill mold containing two cylindrical cavities $19 \mathrm{~mm}$ in diameter by $178 \mathrm{~mm}$ long. Following cooling, the bars were removed from the mold, cropped and placed in a $19.1 \mathrm{~mm}$ i.d., high purity alumina open ended tube for directional solidification in a modified Bridgeman apparatus under flowing high purity argon. The as-cast $33 \mathrm{Ni}-33 \mathrm{Al}-31 \mathrm{Cr}-3 \mathrm{Mo}$ bar was superheated to $1855 \pm 15 \mathrm{~K}$ through induction heating of a susceptor, where the molten metal temperature was monitored by a Type $\mathrm{C} W / \operatorname{Re}$ thermocouple in a protective ceramic tube inserted to about the mid-point of the melt. To achieve preferential solidification, the $\mathrm{Al}_{2} \mathrm{O}_{3}$ tube containing the molten metal was pulled through a hole in a fixed position water-cooled copper baffle. In addition to direct radiation to the copper baffle, the heat dissipation, necessary for solidification, was also partially achieved through conduction to the water-cooled pull ram; all together, this geometry yielded thermal gradients at the liquid/solid interface of about $8-10 \mathrm{~K} / \mathrm{mm}$. Actual directional solidification was conducted at withdrawal rates of $7.6,12.7,25.4,50.8,127,254$ and $508 \mathrm{~mm} / \mathrm{h}$ to produce aligned regions about $100 \mathrm{~mm}$ long; except at the slowest speed, where, due to operating time limits on the equipment, the DS length was about $50 \mathrm{~mm}$. 
Compression specimens, fracture toughness bend bars, and chemical and metallography samples were taken from the aligned region in each DS bar by wire electrodischarge machining (EDM). The compression specimens were $8 \times 4 \times 4 \mathrm{~mm}$ in size with the $8 \mathrm{~mm}$ sample length parallel to the growth axis, and they were tested in the as-EDM'ed surface condition. The fracture toughness bars, $50 \mathrm{~mm}$ long and $6 \times 3 \mathrm{~mm}$ in cross-section, were machined in accordance to the ASTM-399 bend specimen geometries [25]. Prior to toughness testing, the as-cast EDM layers were removed by grinding the flat faces of the specimens on emery paper to a finish of 600 grit.

Constant velocity testing was conducted in a universal testing machine at 1200 and $1300 \mathrm{~K}$, where each sample was compressed along its length (rod growth axis) between two solid SiC push bars. All testing was conducted in air at nominal strain rates varying from $2 \times 10^{-7}$ to $2 \mathrm{x}$ $10^{-4} \mathrm{~s}^{-1}$. The autographically recorded load - time curves were converted to true stresses, strains and strain rates via the offset method in combination with a normalization to the final specimen length and the assumption of constant volume.

Fracture toughness of the alloys at room temperature was measured in three-point bending in accordance with ASTM E399 [25], with one main exception: The precracks were generated by using the bridge indentation technique [26] instead of cyclic fatigue. The test specimens were loaded at a stroke rate of $0.2 \mathrm{~mm} / \mathrm{min}$ on a $24 \mathrm{~mm}$ support span. The specimen stability was monitored by either a clip gage, as required by E399, or by a strain gage placed on the compressive face of the specimen [27]. Both methods were adequate for assessing the specimen stability. 
Light optical techniques were used to conduct detailed metallographic observations on both the longitudinal and transverse polished samples taken from the aligned region of each directionally solidified rod. The locations of the metallographic specimens taken from the DS rods are schematically illustrated in Fig. 2(a); this figure also shows the approximate position of the samples utilized for alloy chemistry. Chemical analysis to determine both major and minor solute metallic elements $(\mathrm{Ni}, \mathrm{Al}, \mathrm{Cr}, \mathrm{Mo}, \mathrm{Si})$ was performed by an inductively the coupled plasma (ICP) technique, while the concentrations of nitrogen and oxygen were determined by an inert gas fusion method, and the carbon level was measured by the combustion extraction method.

\section{Results}

\section{As-DS material}

Typical examples of the transverse microstructures found in DS Ni-33Al-31Cr-3Mo are presented in Figs. 2(b-d) and 3. For six of the seven growth velocities $(7.6 \mathrm{~mm} / \mathrm{h}$ (Fig. 3(a) and $25.4 \mathrm{~mm} / \mathrm{h}$ through $508 \mathrm{~mm} / \mathrm{h}$ (Figs. 2(b-d) and Figs (3(c-f)) the structure consisted of cells enclosed by relatively thick intercellular regions. Each cell consists of alternating plates of $\mathrm{NiAl}$ (dark contrast) and $\mathrm{Cr}$ alloyed with Mo (light contrast) which form a radial pattern extending from the center outward toward the cell boundary, as is best illustrated by Fig. 3(a). The major difference between the cell interior and the intercellular region lie in the thickness of the lamellae, where coarser alternating layers of $\mathrm{NiAl}$ and $\alpha-(\mathrm{Cr}, \mathrm{Mo})$ existed in the intercellular regions, while much thinner lamellae were formed within the cells. While precise cell diameter measurements have not been made, examination of transverse sections of cells formed after growth at 25.4 (Fig. 3(c)), 50.8 (Figs. 2(b-d)), 127 (Fig. 3(d)), 254 (Fig. 3(e)) and 508 (Fig. 3(e)) $\mathrm{mm} / \mathrm{h}$ indicate that the diameters are nominally equal. Although no strong dependence of cell 
diameter on the faster growth rates $(\geq 25.4 \mathrm{~mm} / \mathrm{h}$ ) was observed, the cells formed after $\mathrm{ds}$ 'ing at $7.6 \mathrm{~mm} / \mathrm{h}$ (Fig.3(a)) are significantly larger than those formed at the faster rates.

In the case of alloy DS at $12.7 \mathrm{~mm} / \mathrm{h}$, transverse sections (Fig. 3(b)) revealed only lamellar eutectic grains consisting of alternating layers of $\alpha-(\mathrm{Cr}, \mathrm{Mo})$ and NiAl. No intercellular regions could be seen between grains under light optical conditions; thus such regions are extremely thin $(<1 \mu \mathrm{m})$ or nonexistent. Furthermore, examination of the lamellar eutectic grains, as well as cells and the intercellular regions formed after growth at other conditions, only showed the presence of plate-like configurations of $\mathrm{NiAl}$ and $\alpha-(\mathrm{Cr}, \mathrm{Mo})$. Neither third phases nor other morphologies of $\alpha-(\mathrm{Cr}, \mathrm{Mo})$ and $\mathrm{NiAl}$ were observed in any of the DS alloys. Excluding the formation of cells, the most significant effect of growth velocity was the refinement of the lamellae within the cells (lamellar eutectic grains), where thickness (spacing) of the lamellae decreased with increasing growth rate.

In general the transverse microstructure found at various sections along the length of the aligned regions of the DS rods was consistent. An example of this relative uniformity is shown in Figs. 2(b-d) which illustrates the structure near the end, middle and start of the aligned region for a Ni-33Al-31Cr-3Mo bar grown at $50.8 \mathrm{~mm} / \mathrm{h}$. Microstructural examination of the longitudinal sections revealed that the current DS conditions had generally little effect on the alignment of the lamellae. Both for growth at $12.7 \mathrm{~mm} / \mathrm{h}$ (Fig. $4(\mathrm{a}, \mathrm{b})$ ), which did not have intercellular regions, and all the other the ds conditions, which resulted in intercellular regions (Fig. 4(c,d), the lamellae within individual cells tended to be aligned with the growth axis. On the other hand, the 
lamellae within the intercellular regions were not aligned with the growth axis (Fig. 4(d)).

Lastly, examination of the longitudinal sections did not revealed any transverse growth faults from disruptions during the directional solidification processing.

Alloy chemistry (Table 1) was measured on samples taken from the aligned region of each rod (Fig. 2(a)), and with the exception of the rod grown at $7.6 \mathrm{~mm} / \mathrm{h}$, all the materials had compositions near the desired Ni-33Al-31 Cr-3Mo. Additionally all the rods contained minor amounts of $\mathrm{C}, \mathrm{N}$ and $\mathrm{O}$ along with from 0.1 to 0.2 at $\% \mathrm{Si}$. The latter impurity is a result of the initial induction melting in crucibles which contained a $\mathrm{SiO}_{2}$ binder.

Table 1. Chemistry in the aligned regions of DS Ni-33Al-31Cr-3Mo

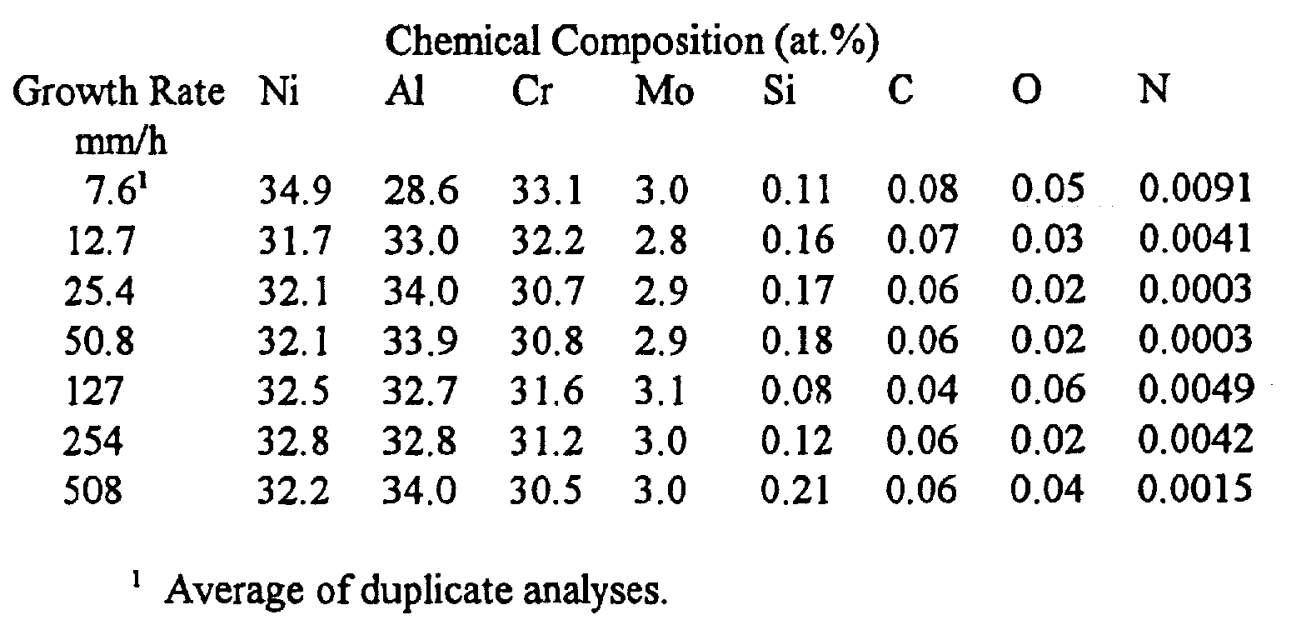

\section{Compressive Properties}

Typical examples of the true compressive stress-strain diagrams from constant velocity testing of DS Ni-33Al-31Cr-3Mo are presented in Fig. $5(\mathrm{a}, \mathrm{b})$ as a function of nominal strain rate for samples grown at $50.8 \mathrm{~mm} / \mathrm{h}$. At both 1200 (Fig. 5(a)) and $1300 \mathrm{~K}$ (Fig. 5(b)), the stress-strain curves are similar in appearance, where, in general, rapid work hardening occurred through $\sim 1 \%$ strain to a maximum stress which was then followed by slow strain softening. Also, as would be 
normally expected, strength decreased with decreasing strain rate at both test temperatures and at each strain rate the strength at $1200 \mathrm{~K}$ is greater than that measured at $1300 \mathrm{~K}$.

The effect of growth rate on the 1200 and $1300 \mathrm{~K}$ true compressive stress - strain behavior of DS Ni-33Al-31Cr-3Mo is illustrated in Fig. 6. For tests undertaken at $1200 \mathrm{~K}$ and a nominal strain rate of $2 \times 10^{-4} \mathrm{~s}^{-1}$ (Fig. 6(a)), strength increases with increasing growth rate; such a simple relationship, however, is not maintained for slower strain rate testing at $1200 \mathrm{~K}$ (Fig. 6(b)). In this case the two samples grown at rates an order of magnitude apart (25.4 and $254 \mathrm{~mm} / \mathrm{h}$ ) are clearly stronger at $\sim 1.5 \times 10^{-6} \mathrm{~s}^{-1}$ than specimens grown at faster or slower speeds. At $1300 \mathrm{~K}$ (Fig. 6(c)) the fastest growth rate $(508 \mathrm{~mm} / \mathrm{h})$ and a much slower intermediate growth rate $(25.4$ $\mathrm{mm} / \mathrm{h}$ ) produced somewhat stronger materials at both $\sim 2 \times 10^{-4}$ and $\sim 1.5 \times 10^{-6} \mathrm{~s}^{-1}$. Examination of all the conditions shown in Fig. 6 does not show any consistency between strength and growth rate with the exception that the slowest growth rate $(7.6 \mathrm{~mm} / \mathrm{h})$ always resulted in the weakest DS alloy.

The true compressive flow stress - strain rate - temperature data for DS Ni-33Al-31Cr-3Mo are given in Fig. 7(a) at $1200 \mathrm{~K}$ and Fig. 7(b) at $1300 \mathrm{~K}$. For this analysis flow stresses and strain rates were evaluated at 1 pct strain from the constant velocity tests (Figs. 5 and 6). Over the current range of test conditions $\left(\sim 2 \times 10^{-4}\right.$ to $\left.2 \times 10^{-7} \mathrm{~s}^{-1}\right)$ no one particular growth condition appeared to possesses superior properties. In fact, the $1300 \mathrm{~K}$ data (Fig. 7(b)) suggest that for growth rates $\geq 12.7 \mathrm{~mm} / \mathrm{h}$ all the DS alloys have about the same strength levels. While this conclusion generally holds for $1200 \mathrm{~K}$ testing (Fig. 7(a)), the material grown at 25.4 and 254 
$\mathrm{mm} / \mathrm{h}$ and tested at $\sim 1.5 \times 10^{-6} \mathrm{~s}^{-1}$ do imply a possible strength advantage; additional testing at $2 \times$ $10^{-7} \mathrm{~s}^{-1}$ needs to be undertaken to study this possibility. Lastly, as is indicated by the stress strain diagrams (Fig. 6), the alloy DS at the slowest rate $7.6 \mathrm{~mm} / \mathrm{h}$ has inferior properties compared to the other growth conditions.

\section{Fracture Toughness}

The majority of the fracture toughness specimens exhibited either unstable crack extension or multiple, unstable crack extensions followed by crack arrests, implying little in the way of ductility. For some specimens, measurement of the precrack length was difficult due to the microstructure (Figs 2-4). Thus, these cracks were marked via a dye penetrant (DP-40, Sherwin Inc., South Gate, $\mathrm{Ca}$.) or by heat tinting at $983 \mathrm{~K}$ for 1 hour in air. The heat tinting was generally adequate for marking precracks, however the dye penetrant was not.

One of the main difficulties in measuring fracture toughness was the generation of an acceptable precrack. Because the DS Ni-33Al-31Cr-3Mo exhibited a relatively low elastic modulus and large fracture toughness, the precracking fixture and specimen parameters outlined in PS070 [27], which are appropriate for ceramics materials, tended to generate cracks of excessive length. Shorter precracks were attained by using a narrow bridge span $(\sim 2 \mathrm{~mm})$ and by sharpening the starter notch, which was cut by EDM, with a razor blade and diamond paste.

The room temperature toughness data is summarized as a function of growth rate in Table 2 . The fracture toughness of the DS Ni-33Al-31Cr-3Mo seems to fall into two regimes, At the two slower growth rates, a toughness of about $12 \mathrm{MPa} \cdot \sqrt{\mathrm{m}}$ was obtained; however after DS at 25.4 
$\mathrm{mm} / \mathrm{h}$ or faster the toughness values increased $\sim 40 \%$ to about $17 \mathrm{MPa} \cdot \sqrt{\mathrm{m}}$. Although, to date, only one fracture toughness sample has been tested for each growth rate condition, the consistency of the results in Table 2 strongly suggests that growth rates exceeding $12.7 \mathrm{~mm} / \mathrm{h}$ will yield improved fracture toughness.

Table 2 - Measured fracture toughness of directionally solidified Ni-33Al-31Cr-3 Mo as a function of growth rate.

$\begin{array}{cc}\text { Growth Rate, } \mathrm{mm} / \mathrm{h} & \text { Fracture Toughness, } \mathrm{MPa} \cdot V_{\mathrm{m}} \\ 7.62 & 12.3 \\ 12.7 & 12.2 \\ 25.4 & 16.8 \\ 50.8 & 16.9 \\ 127 . & 17.6 \\ 254 & 16.9 \\ 508 & 14.9\end{array}$

Discussion

\section{As-DS structure}

Based on the microstructures for Ni-33Al-31Cr-3 Mo grown at $12.7 \mathrm{~mm} / \mathrm{h}$ (Figs. 3(b)and 4(a,c)) and those DS at faster rates (Figs. 2(b-d), 3(c-f) and 4(b,d)), it was surprising to find intercellular regions in the alloy grown at $7.6 \mathrm{~mm} / \mathrm{h}$ (Fig. 3(a)). Alloy chemistry (Table 1) appears to be directly responsible for this anomalous behavior, where the $\mathrm{Al}, \mathrm{Cr}$, and $\mathrm{Ni}$ levels deviated considerably from the desired values of $33 \% \mathrm{Al}, 31 \% \mathrm{Cr}$ and $33 \% \mathrm{Ni}$. Such a divergence, particularly the $\sim 4.5$ at \% deviation in $\mathrm{Al}$ content, indicates that the chemistry was significantly removed from the accepted eutectic composition, even though the microstructure (Fig. 3(a)) was eutectic-like in appearance. In comparison to the alloy grown at the slowest conditions, all the other six DS rods had much smaller differences between the ideal compositon and the actual, measured chemistry: for example the maximum deviation in $\mathrm{Al}$ content was 1 at $\%$ (bars grown 
at 25.4 and $508 \mathrm{~mm} / \mathrm{h})$, the maximum deviation in Cr content was 1.2 at. $\%(12.7 \mathrm{~mm} / \mathrm{h})$ and the maximum deviation in $\mathrm{Ni}$ content was 1.3 at. $\%(12.7 \mathrm{~mm} / \mathrm{h})$.

Walter and Cline [20] examined the microstructures of several NiAl-XCr-YMo $(\mathrm{X}+\mathrm{Y}=34)$ alloys after directional growth at $6.3,12.7$ and $25.4 \mathrm{~mm} / \mathrm{h}$, and there are two major differences between their observations and those in the present study. First, they found NiAl dendrites in a NiAl-31.3Cr-2.7Mo alloy grown at $25.4 \mathrm{~mm} / \mathrm{h}$, while the slower growth rates resulted in lamellar eutectic grains. Such a grain structure was also obtained in Ni-33Al-31Cr-3Mo DS at $12.7 \mathrm{~mm} / \mathrm{h}$ (Fig. 3(b)) in the current work; however NiAl dendrites were not found after 25.4 $\mathrm{mm} / \mathrm{h}$ (Fig. 3(c)) growth or any other faster growth rate, for that matter. Secondly, Walter and Cline [20] only observed cells with the radial pattern of $\mathrm{NiAl}$ and $\alpha-(\mathrm{Cr}, \mathrm{Mo})$ plates in DS alloys containing more that 7 at pct $\mathrm{Mo}$; in contrast we saw the radial arrangement of lamella in the cells formed under almost all growth conditions (Figs. 2(b-d), 3(a), 3(c-f)). These two discrepancies are difficult to explain. While alloy composition (Table 1) is the probable cause for cell formation in our alloy DS at $7.6 \mathrm{~mm} / \mathrm{h}$ (Fig. 3(a)), it is difficult to believe that these two major differences between Walter and Cline's study [20] and the present study are solely due to small alloy chemistry deviations.

One other microstructural anomaly appears to exist between the current work and a previous study by Walter and Cline [19]. After directional solidification of NiAl-34Cr, they found that the cell size substantially decreased as the growth rate $(\geq 25.4 \mathrm{~mm} / \mathrm{h})$ increased. This is not the case for Ni-33Al-31 Cr-3Mo (Figs. 2 (b-d) and 3(c-f)), where, for all practical purposes, cell 
diameter is independent of growth velocity. While the differences in alloy chemistry and strengthening phase morphology do not allow a direct comparison between these studies, the lack of an easily discernible relationship between cell size and growth rate in Ni-33Al-31 Cr-3Mo is surprising.

\section{Mechanical properties}

The unexpected deviation in alloy chemistry (Table 1) is the most likely reason for the inferior elevated temperature strength properties (Figs. 6 and 7) of the material DS at $7.6 \mathrm{~mm} / \mathrm{h}$. Although no unexpected second phases were found in this material under light optical examination up to 1000 magnifications, the grossly deficient Al level must have affected the composition of the NiAl matrix and the volume fraction of NiAl. While both of these factors can influence the mechanical properties, within the limits of the present work, the room temperature toughness (Table 2) does not appear to be significantly affected, as both the Al-deficient alloy grown at $7.6 \mathrm{~mm} / \mathrm{h}$ and the more ideal eutectic composition (Table 1) DS at $12.7 \mathrm{~mm} / \mathrm{h}$ have similar toughness values.

Examination of the flow stress - strain rate - temperature data for directionally solidified Ni-33Al-31Cr-3Mo in Fig. 7 does not reveal any optimum growth condition for the best strength properties; all ds'ing rates at or exceeding $12.7 \mathrm{~mm} / \mathrm{h}$ have nearly equivalent values. This result appears to be different from that of Walter and Cline [19], who suggested that the 1073 and $1273 \mathrm{~K}$ strength of $\mathrm{NiAl}-34 \mathrm{Cr}$ was dependent on the directional solidification rate. Their observation, however, might be a simple artifact of their test conditions, where all samples were deformed at a single strain rate $\left(\sim 1.3 \times 10^{-4} \mathrm{~s}^{-1}\right)$. For example in the current study DS 


\section{Summary of Results}

The microstructure, elevated temperature compressive properties and room temperature toughness has been determined for the eutectic system Ni-33Al-3 1Cr-3Mo after being directionally solidified at rates ranging from 7.6 to $508 \mathrm{~mm} / \mathrm{h}$. While lamellar eutectic grains were formed at $12.7 \mathrm{~mm} / \mathrm{h}$, faster growth rates resulted in cellular microstructures. Testing at 1200 and $1300 \mathrm{~K}$ over the strain range from $10^{-4}$ to $10^{-7} \mathrm{~s}^{-1}$ did not indicate an optimum growth rate; likewise no single growth condition produced a significant toughness advantage. The mechanical behavior, taken altogether, suggests that $\mathrm{Ni}-33 \mathrm{Al}-31 \mathrm{Cr}-3 \mathrm{Mo}$ grown at rates from $25.4 \mathrm{~mm} / \mathrm{h}$ to $254 \mathrm{~mm} / \mathrm{h}$ will have nominally equivalent properties 


\section{References}

1.. M. V. Nathal, Ordered Intermetallics - Physical and Mechanical Behavior, C. T. Liu, R. W. Cahn and G. Sauthoff, eds. (Kluwer Academic Publishers, Dordrecht, The Netherlands, 1992), pp. 541-563.

2. W. S. Walston, R. D. Field, J. R. Dobbs, D. F. Lahrman and R. Darolia, Structural Intermetallics, R. Darolia, J. J. Lewandowski, C. T. Liu, P. L. Martin, D. B. Miracle and M. V. Nathal, eds. (The Minerals, Metals \& Materials Society, Warrendale PA, 1993), pp. 523-532.

3. M. Rudy and G. Sauthoff, Mater. Sci. Eng. 81, 525-530 (1986).

4. G. Sauthoff, Structural Intermetallics, R. Darolia, J. J. Lewandowski, C. T. Liu, P. L. Martin,

D. B. Miracle and M. V. Nathal, eds. (The Minerals, Metals \& Materials Society, Warrendale PA, 1993), pp. 845-860.

5. B. Zeumer and G. Sauthoff, Intermetallics, 5, 563 (1997).

6. R. Darolia and W. S. Walston, Structural Intermetallics-1997, M. V. Nathal, R. Darolia, C. T. Liu, P. L. Martin, D. B. Miracle, R. Wagner and M. Yamaguchi, eds. (The Minerals, Metals \& Materials Society, Warrendale PA, 1997), pp. 585-594.

7. R. Darolia, Structural Intermetallics, R. Darolia, J. J. Lewandowski, C. T. Liu, P. L. Martin, D. B. Miracle and M. V. Nathal, eds. (The Minerals, Metals \& Materials Society, Warrendale PA, 1993), pp. 495-504.

8. R. Darolia, W. S. Walston and M. V. Nathal, Superalloys 1996, R. D. Kissinger, D. J. Deye, D. L. Anton, A. D. Cetel, M. V. Nathal, T. M. Pollock and D. A. Woodford, eds. (The Minerals, Metals \& Materials Society, Warrendale PA, 1996), pp. 561-570.

9. W. S. Walston and R. Darolia, Structural Intermetallics-1997, M. V. Nathal, R. Darolia, C. T. Liu, P. L. Martin, D. B. Miracle, R. Wagner and M. Yamaguchi, eds. (The Minerals, Metals \& Materials Society, Warrendale PA, 1997), pp. 613-619.

10. J. Klöwer and G. Sauthoff, Z. Metallkde, 82 (1991) 510-518.

11. R. Darolia, D. F. Lahrman, R. D. Field, J. R. Dobbs, K. M. Chang, E. H. Goldman and D. G. Konitzer, Ordered Intermetallics - Physical and Mechanical Behavior, C. T. Liu, R. W. Cahn and G. Sauthoff, eds. (Kluwer Academic Publishers, Dordrecht, The Netherlands, (1992), pp. 679-698.

12. D. R. Johnson, Ph.D. Thesis, The University of Tennessee, Knoxville, TN (1994).

13. S. M. Joslin, Ph.D. Thesis, The University of Tennessee, Knoxville, TN (1995). 
14. T. M. Pollock and D. Kolluru, Micromechanics of Advanced Materials: A Symposium in Honor of Professor James' Li's $70^{\text {th }}$ Birthday, S. N. G. Chu, P. K. Liaw, R. J. Arsenault, K. Sadananda, K. S. Chan, W. W. Gerberich, C. C. Chau and T. M. Kung, eds. (The Minerals, Metals \& Materials Society, Warrendale PA, 1995), pp. 205-212.

15. J. M. Yang, JOM, 49 (1997) 40-43.

16. J. M. Yang, S. M. Jeng, K. Bain and R. A. Amato, Acta Mater., 45 (1997) 295-305.

17. A. Misra, Z. L. Wu, M. T. Kush and R. Gibala, Mater. Sci. Eng., A239-240 (1997) 75-87.

18. D. V. Kolluru and T. M. Pollock, Acta Mater. 46 (1998) 2859-2876.

19. J. L. Walter and H. E. Cline, Metall. Trans., 1 (1970) 1221-1229.

20. H. E. Cline and J. L. Walter, Metall. Trans., 1 (1970) 2907-2917

21. H. E. Cline, J. L. Walter, E. Lifshin and R. R. Russell, Metall. Trans., 2 (1971) 189-194.

22. M. McLean, Directionally Solidified Materials for High Temperature Service, The Metals Society, London, 1983

23. S. V. Raj, I. E. Locci and J. D. Whittenberger, Creep Behavior of Advanced Materials for the $2 I^{\text {st }}$ Century (edited by R. S. Mishra, A. K. Mukherjee and K. Linga Murty), (The Minerals, Metals \& Materials Society, Warrendale PA, 1998), in press.

24. J.D. Whittenberger, R.D. Noebe, D.R. Johnson and B.F. Oliver. Intermetallics 5 (1997) 173-184.

25. "Standard Test Method for Plane-Strain Fracture Toughness of Metallic Materials." Test Method E 399-90, Annual Book of ASTM Standards, 03.01, ASTM, West Conshohocken, PA, 1990.

26. J.A. Salem, L.J. Ghosn, and M.G. Jenkins, Ceramic Engineering and Science Proceedings, 19 (1998) 587-594.

27. "Standard Test Method for Fracture Toughness of Advanced Ceramics," Test Method PS070, American Society for Testing Materials Annual Book of Standards, 15.01 ASTM, West Conshohocken, PA, 1998.

28. I.E. Locci, S.V. Raj, J.D. Whittenberger, J.A. Salem and D.J. Keller. "Microstructure, Creep and Fracture Toughness of Directionally Solidified NiAl/(Cr,Mo) Alloys Modified wiht $\mathrm{Hf}, \mathrm{Si}$, 
Ta, Ti Additions" High-Temperature Ordered Intermetallic Alloys VIII, Vol. ; (eds. ), Materials Research Society, Pittsburgh, PA, 1999, pp.

29. D.R. Johnson, X.F. Chen, B.F. Oliver, R.D. Noebe and JDW. Intermetallics 3 (1995) 99-113. 


\section{Figure Captions}

1. Comparison of the flow strength - strain rate results for four Ni-33Al-31Cr-3Mo rods directionally solidified at $12.7 \mathrm{~mm} / \mathrm{h}$ and then tested in compression (open symbols) and tension (filled symbols) at $1300 \mathrm{~K}$ [23].

2. Schematic drawing of a DS Ni-33Al-31Cr-3Mo rod (a) and three photomicrographs of sections showing the uniformity of the transverse microstructure near the end (b), middle (c), and start (d) of the aligned regions for the rod DS at $50.8 \mathrm{~mm} / \mathrm{h}$.

3. Typical photomicrographs of transverse sections of DS Ni-33Al-31Cr-3Mo rods grown at (a) 7.6, (b) 12.7 , (c) 25.4 , (d) 127 , (e) 254 and (f) $508 \mathrm{~mm} / \mathrm{h}$.

4. Typical photomicrographs of longitudinal sections of DS Ni-33Al-31Cr-3Mo rods grown at $(a, c) 12.7 \mathrm{~mm} / \mathrm{h}$ and $(b, d) 508 \mathrm{~mm} / \mathrm{h}$. The growth direction is vertical.

5. True compressive stress - strain diagrams for DS Ni-33Al-31Cr-3Mo grown at $50.8 \mathrm{~mm} / \mathrm{h}$ as a function of nominal strain rate at (a) $1200 \mathrm{~K}$ and (b) $1300 \mathrm{~K}$.

6. True compressive stress - strain diagrams for DS Ni-33Al-31Cr-3Mo as a function of growth rate at (a) $1200 \mathrm{~K}-2 \times 10^{-4} \mathrm{~s}^{-1} \mathrm{~K}$, (b) $1200 \mathrm{~K}-1.6 \times 10^{-4} \mathrm{~s}^{-1} \mathrm{~K}$, and (c) $1300 \mathrm{~K}-2 \times 10^{-4} \mathrm{~s}^{-1}$ (filled symbols) \& $-1.5 \times 10^{-6} \mathrm{~s}^{-1}$ (open symbols).

7. True compressive flow stress - strain rate behavior for $\mathrm{DS} \mathrm{Ni}-33 \mathrm{Al}-31 \mathrm{Cr}-3 \mathrm{Mo}$ as a function of growth rate at (a) $1200 \mathrm{~K}$, and $1300 \mathrm{~K}$. 


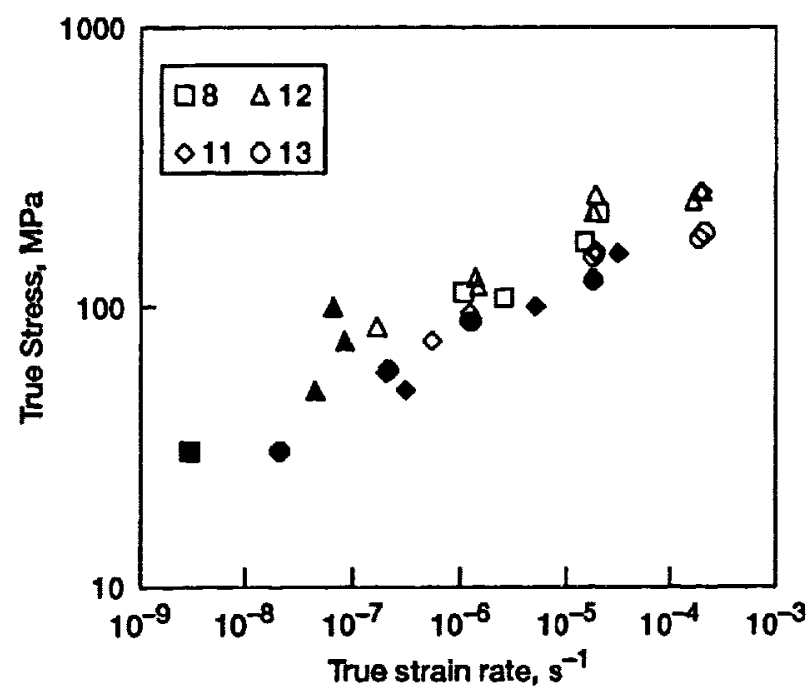

Figure 1. 


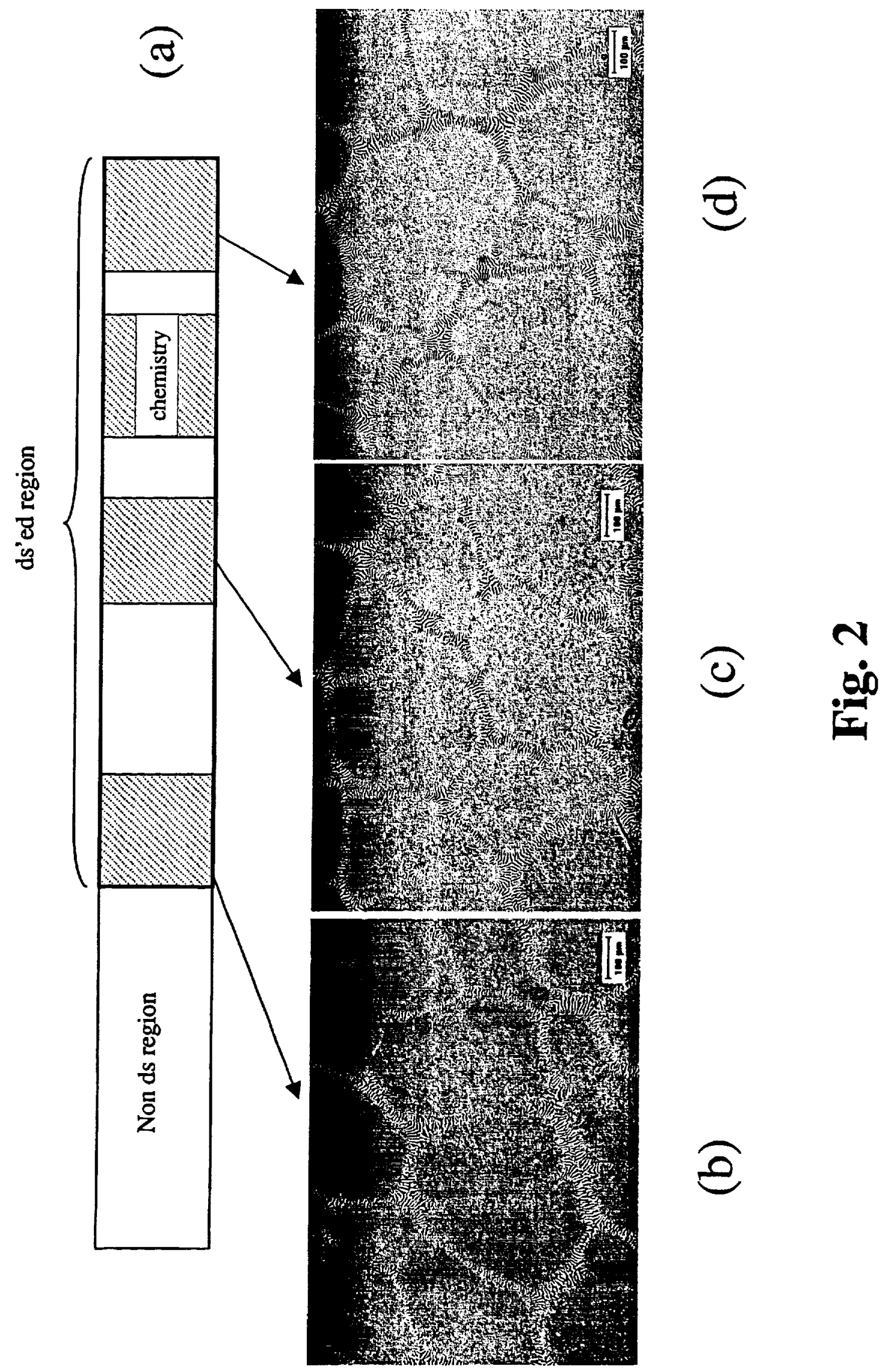



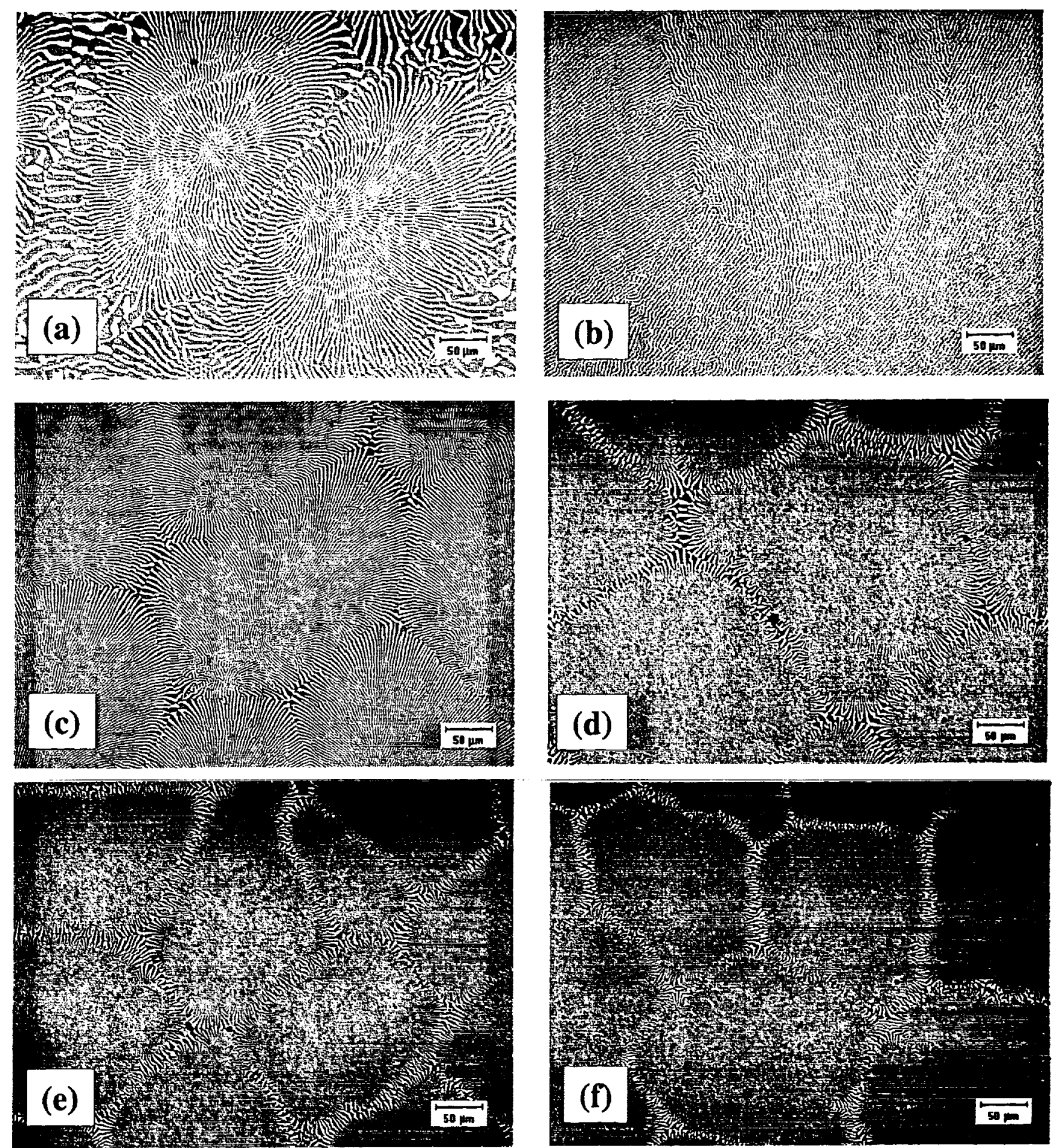

Fig. 3 

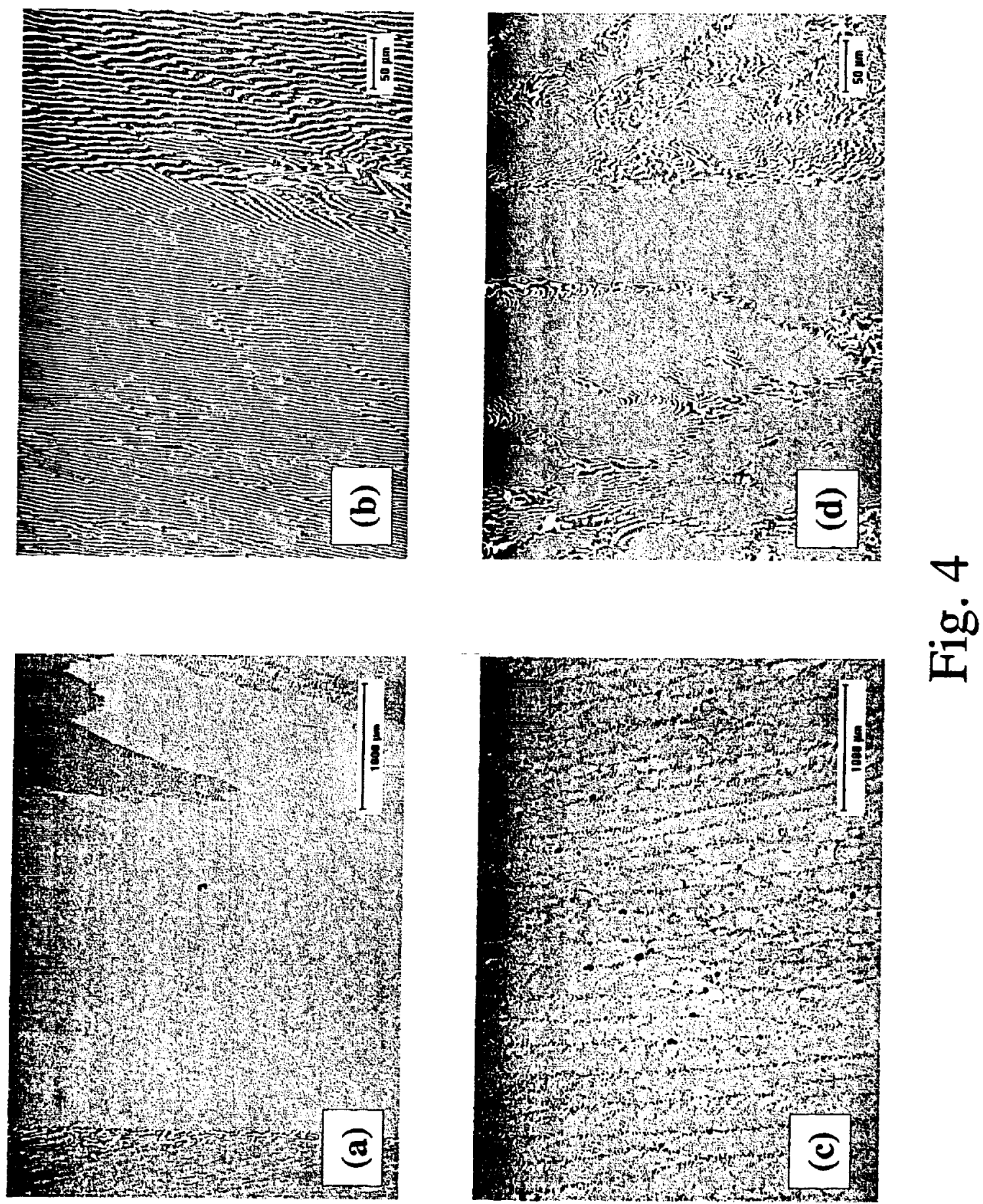

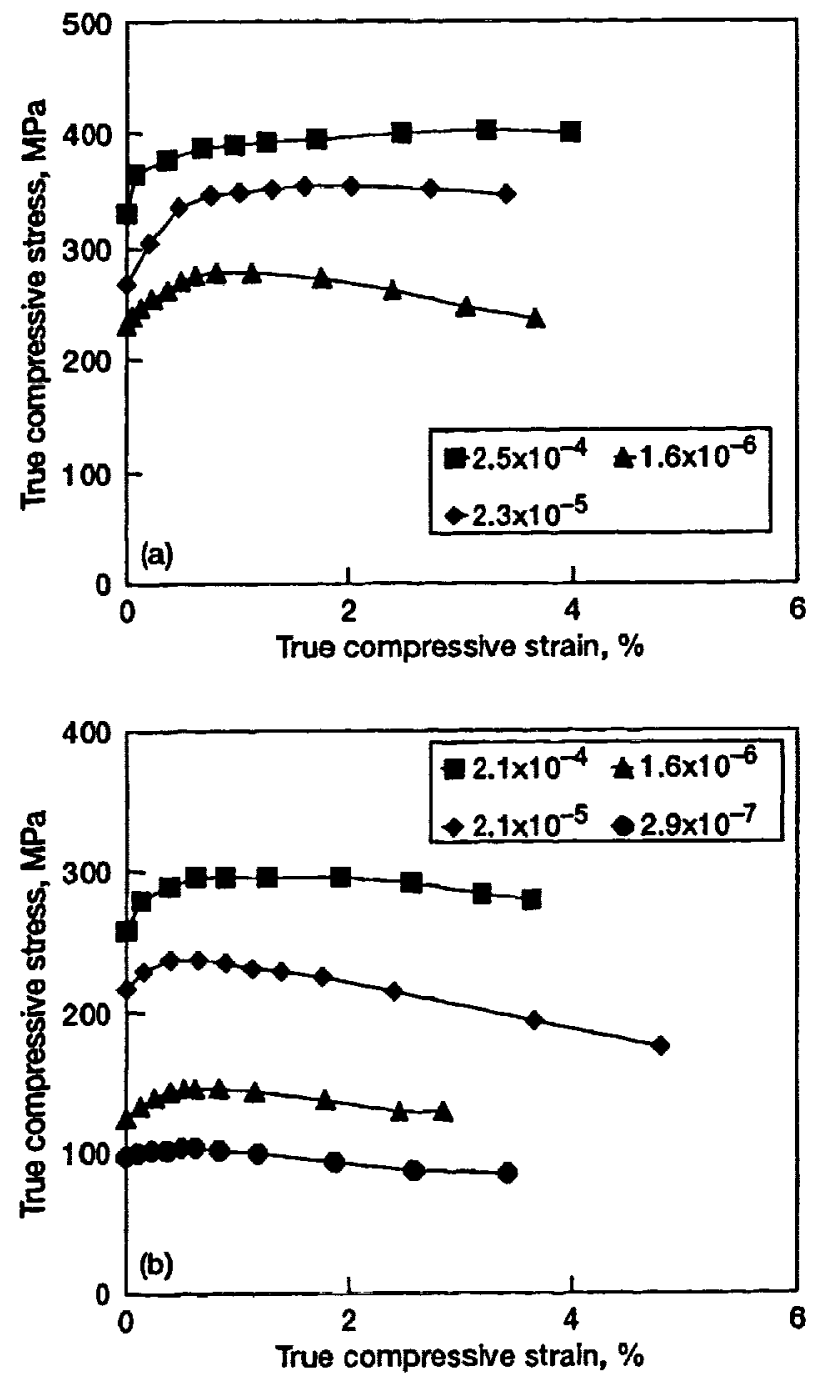